\title{
Social Protection, Social Security and Social Service in a Development Context : Transformative Social Policy Approach
}

Ilcheong Yi United Nations Research Institute for Social Development(Geneva, Switzerland)

\section{목차}

I. Introduction

II. Defining Social Protection, Social Security, Social Service within Development Context

III. Development of Social Policies in Developing Countries

IV. Universalism and Targeting Approach :

A Principle and A Method

V. A New Social Policy Approach: Transformative Social Policy

Vl. Conclusion

\section{Introduction}

Despite the emphasis on social protection and social security as human rights, only a small segment of the world's population (only about $20 \%$ of the world's working-age population and their families) actually enjoys that right and more than half of the world's population lack any type of protection at all. In sub-Saharan Africa and South Asia, the number of 
people with access to even the most rudimentary protection is estimated to be less than 10 per cent(International Labour Organization, 2010). Together with crises of food, energy and climate change, the global economic crisis since 2007 is more likely to worsen the situation in terms of its coverage and the level of benefits due to both global and national financial constraints, in particular in developing countries. Recent research based on fiscal projection data published by the IMF for 126 low and middle income countries shows there will be a further contraction of government spending in 2010-2011 through wage cuts, reduction of subsidies and more targeted schemes of social protection which will inevitably result in the reduction of social protection and social security (Ortiz et al., 2010).

Although increased interest in social protection and social security as a policy approach to reduce poverty and inequality is a recent phenomenon, social security and social protectionas either normative or practical components of development strategy have been consistently emphasized in various documents of the international since the Second World War. Article 25 and 26 of the Universal Declaration of Human Rights (1948) clearly states the right to social services meeting basic necessities such as food, clothing, housing and medical care, and education and the right to security in the event of unemployment, sickness, disability, widowhood, old age or other lack of livelihood in circumstances beyond one's control. Such transfers and services as medical care, sickness benefit, unemployment benefit, old-age benefit, employment injury benefit, family benefit, maternity benefit, invalidity benefit and survivors'benefit were again emphasized as worldwide agreed minimum standards by the Social Security (Minimum Standards) Convention of ILO (No.102, 1952)(International Labour Organization, 1952). The Internationl Covenance on Economic, Social and Cultural Rights reaffirmed the importance of social security and social service in articles 9, 10, 11, 12 and 13(General Assembly of United Nations, 1966).

Given the widespread consensus on the expansion of the social protection and social security, the record of social protection and social security is very much disappointing. Why is the coverage so low and how can we expand social protection and social security? Answers to this question is partly related to how social protection and social security are understood, designed and implemented within a broad development strategy to reduce poverty and inequality. How were the policies of social protection and social security interpreted and introduced in the development discourse? What are the implications of 
different social policy approaches to the reduction of poverty and inequality within the context of development? What is the desirable approach to social protection and social security effective in reducing poverty and inequality within a development context?

This paper will address these questions through the examination of the historical evolution of social protection and social security in developing countries, on the one hand, and the efficiency and effectiveness of two contrasting social policy approaches such as universalism and targeting approach, on the other.

\section{Defining Social Protection, Social Security, Social Service within Development Context}

Definitions and interpretations of the boundary of social security and social protection within the context of development are diverse among scholars and international agencies. For instance the ILO defines social protection as the set of public measures that a society provides for its members to protect them against economic and social distress that would be caused by the absence or a substantial reduction of income from work as a result of various contingencies (sickness, maternity, employment injury, unemployment, invalidity, old age, and death of the breadwinner); the provision of health care; and the provision of benefits for families with children. It interprets social protection as much broader and more inclusive than social security since it incorporates non-statutory or private measures for providing social security, but still encompasses traditional social security measures such as social assistance and social insurance (Bonilla Garcia and Gruat, 2003). It is noticeable that education is not included in this definition despite its importance to the development. The definition of the ILO is consistent with that used by the EU, OECD and World Bank.

The definition of social protection by the Asian Development Bank reflecting a regional perspective is much broader and more inclusive since it does not only include social insurance and social assistance policy measures addressing the traditional risks, but also micro and community-based social service programmes and child protection which exists in diverse forms in Asian region. The definition of child conditioned social protection by the UNICEF 
has a strong emphasis on the basic human right aspect of social protection and encompasses social assistance and economic support directed at the family or at the individual child and social services including family and community support and alternative care.

This difference, in a sense, is a reflection of socio-economic changes generating new risks which social protection and social security measures are supposed to address. Understanding social protection and social security as dynamic rather than static concepts urges us to define them in the way to deal with the changing nature of social responses to the risks. We, therefore, define social protection and social security as components of social policy which is defined as "collective interventions directly affecting transformation in social welfare, social institutions and social relations" (Mkandawire, 2001). Social welfare encompasses access to adequate and secure livelihoods and income. Social relations range from the micro to the global levels, encompassing intra-household relations of class, community, ethnicity, gender, etc. Social policy is transformative since it concerns not only the protection aspect but also production, redistribution, and reproduction. This definition has an emphasis on the aspect of social policy organizing economic, social and political institutions for reducing poverty and inequality on the one hand, and facilitating economic growth on the other. In our definition, social policy can include all the measures categorized as either social protection, social security or social service as long as they affect social welfare, social institutions and social relations. Depending on the context, you can find strong social policy components deeply embedded in economic policy also. From now on we will employ this definition of social policy including different measures of social protection, social security and social service.

\section{Development of Social Policies in Developing Countries}

After the Second World War, the establishment of the Bretton Woods Institution and new trading regimes resulted in greater policy space for the national governments in the North and the South which allows the national government to approve cross-border movement of capital, determine domestic interest rates, fix the exchange rate of the national currency, and tax and spend as they saw fit to secure national economic objectives. 
Within this international context and the rapid economic growth after the War, during the period of the 1950s and 1960s the US and rich countries of Europe and the newly independent countries were all moving towards universalism in the social policy sector. Social insurance began to replace social assistance and became a major social security mechanism in most OECD countries (Townsend, 2007). There was a drastic decline in inequality and poverty and improvement insocial conditions in industrial countries. High rates of employment, income security, and more access to social services were realised in those countries. Both market and welfare mechanisms organised according to universalism contributed to reducing inequality and poverty in the North until the early 1970s.

During the first one or two decades after independence some of the decolonised countries in both Africa and Asia also started expanding social services in particular health, education and water and sanitation and made progress in the improvement of living standards. Although the coverage was limited to only a small segment of population, most development planning had a plan to expand social service with the government budget. The spirit of nation building such as the solidarity and egalitarianism backed the plan to expand social service. Many countries in Asia and Africa such as Burma, the Philippines, Thailand, Ceylon, Ghana, Tanzania, and Western Nigeria, except for the poorest ones in the regions, actually spent a significant share of government expenditure on social service leaning towards universal coverage (Myrdal, 1968, Adesina, 2010).

In Latin America, in the late 19th century, some forms of social protection began to evolve in most countries in the region, particularly in the education and health sector. Also countries such as Argentina, Uruguay, Brazil and Chile developed social transfer and service along with Bismarkian style occupational pensions. Organised labour and socialist organisations and liberal supporters contributed to securing some minimal protection and entitlements for formal sector workers in most countries of the region in the early 20th century and in the corporatist regimes of Argentina, Brazil and Mexico further expanded social rights in the form of various social provisions. By the end of the 1960s, all but the poorest states had established the main planks of social welfare, if at times in skeletal form. Health and education were publicly funded, and social insurance systems covered some categories of formal sector workers. Human capital theory and the "basic needs" approach had a strong influence on the social policy field and most countries in Latin America started rapidly expanding literacy 
programmes, primary education, the provision of food to the poor, sanitary works, potable water and affordable housing (Filgueira and Filgueira, 2002). Positive growth rates supported the political inclination to expand social provision. The development of social provision in Latin America during the 1960s and 1970s were so impressive that many countries in the region were placed in the leading group of developing countries in terms of social expenditure, coverage of social provision and human development indicators such as life expectancy and infant mortality(Molyneux, 2007).

The end of the Golden Age of the 1950s and 1960s coincided with the beginning of the dismantlement of institutions of universalism. The 1970s is often described as a crisis in advanced countries, in particular the power houses of capitalism at the time such as the UK and the US which had maintained rapid economic growth and development in social and political dimension. For instance, in the UK struggling with a chronic balance of payments from the late 1960s, the Labour government in office from 1974 to 1979 pursued the strategy of deflating the economy, allowing unemployment to rise, letting average real wages fall and hoping that private investment would restore competiveness instead of extending public control and forcing the pace through public investment. In the US, the key pillars of the postwar social structure of accumulation such as the "limited capital-labor accord", and the "capitalist-citizen accord" which had guaranteed the recognition of unions and collective bargaining, though limited in big industries, and employment and the social welfare state were dismantled (Bowles et al., 1990). The institutions based on universalism were gradually dismantled and the new institutions based on the "free market" model replaced them.

In developing countries, the dismantlement process was much faster because of the structural weakness of institutions for universalism. For instance, in many African countries, financial resources for economic and social development were not based on the revenues from the domestic market but from the world market. Surplus from primary commodity exports was either used for conspicuous consumption of imported goods by urban elites, the sub-elites in bureaucratic employment and labour aristocrats or the surplus was transferred abroad. This pattern of absorption of surpluses constrained the growth of agricultural productivity and the domestic market and perpetuated the dependence of African economies on the growth of world demand for primary goods (Arrighi and Saul, 1973). The economy of underdeveloped domestic industries and an agricultural sector with low productivity, highly dependent upon 
international commodity markets for financial resources, could not provide those countries with the wherewithal to withstand economic crisis in the second half of the 1970s. Authoritarianism relying on the suppression and a very small segment of the society often reinforced disintegration of the society, which accentuated economic failure and dismantlement of social service. In addition, in Africa, the failure of detribalization resulted in persistent instability by ethnic conflict within some countries. The "perverse growth", i.e. growth which undermines rather than enhances the potentialities of the economy for long-term growth, authoritarianism and a disintegrated society were a perfect recipe to drive the rolling back of social transfer and services when there was an exogenous economic crisis (Arrighi, 2002).

In Latin American countries, despite the expanded coverage, most social provision was firmly based on the stratified principle, which is, provision of welfare benefits exclusively to those in the formal sector. In addition, low tax revenues from monopolistic multinational, comprado capital and weak political commitments to redistributive polices ruled out the development of effective, universal welfare systems (Molyneux, 2007, Ferreira and Robalino, 2010). The institutional configuration in Latin America, described as "truncated" welfare states or "conservative-informal", relying on social insurance for those in the formal sector and largely depending on informal arrangements for those in the informal sector, was established during this period and the 1980s consequently saw coexistence of both high social spending and high poverty and inequality across the region because of the exclusion of large portions of the population from any formal social protection coverage (Tulchin and Garland, 2000, Barrientos, 2004, Fiszbein, 2005).

In comparison with Africa and Latin America, many East Asian countries were able to continue both universalistic social policy or more precisely social policy leaning towards universalism in conjunction with rapid economic growth. First of all, the pattern of integration of the economy with the global economy in the region was different from African region. Most successful East Asian economies had strict control on the transfer of surplus abroad. Investment in human capital which they had inherited from their own past including the colonial regime continued despite the low level of available resources. Another factor notable is an abundant surplus labour. Different to Africa, most countries in East Asia had "unlimited supplies of educated labour". Different to Latin American countries, they could successfully combine the educated labour with the capital and natural resource intensive 
techniques in the process of adopting western style industrialization, which contributed to creating the bigger formal sector than African and Latin American countries (Arrighi, 2002).

The successful integration of labour into the formal sector was in part due to the intervention of the state into both economic and political spheres. Political intervention into industrial relations and business characterized as suppression, cooptation and negotiation succeeded in maintaining low labour costs but yielding high capital incomes which were directed to invest in industries within countries. It contributed to expanding formal sector work, social insurance for these workers, increasing tax bases and consequently growing the economy(Yi, 2010, Ringen et al., 2011). Although wages on average were low, the income gap was not big. There were also various kinds of direct and indirect measures to enhance living standards of workers and farmers which were provided directly from the state or through the companies. Various types of occupational welfare benefits based on lifelong employment were provided to most workers in both small and big companies. Consistent and strong control on the rice price, which was common in most East Asian countries, to a certain extent could protect both farmers and workers from income insecurity (David and Huang, 1996). Gaps between marginal returns of industry and agriculture were continuously adjusted by this rice price control by the government, which facilitated relatively smooth structural change from an agriculture dominant economy to a manufacturing centered economy. Universal social provision or a move towards universalism in particular in education and health were aimed at covering the industrial workers in urban areas, first, but there were consistent efforts to provide equal access to the rural residents (Kwon and Yi, 2009, Yi, 2010). Increasingly educated workers enabled the introduction of the high tech and value added industrial sector which in turn facilitated higher education in the 1970s, for example in both Taiwan and Korea.

The move towards universalism in both developed and developing countries had a point of divergence due to various international and national structural changes from the late 1970s. The collapse of the Bretton Woods system, the establishment of OPEC, and increasing financial and trade openness were combined with various policy errors to worsen the situation of both economic and social development. The neo-liberalist ideology became dominant at both international and national level political economy as the Cold War system collapsed in the late 1980s. Specific conditions of some countries, such as the transition economies and the countries mainly trading with Soviet economy such as Finland, resulted 
in them experiencing a second wave of structural shock in the 1990s. With rapid technological change and a dismantled Fordist system of production, in most advanced economies full employment industrialization began to be replaced by the twin process of de-industrialisation and tertiarisation of industry. Preconditions and policy tools for Keynesian style demand-driven macro-economic management became gradually dismantled. The fiscal deficit suffered by many advanced countries strengthened the argument for the retrenchment of the welfare state. This affected the international aid strategy of developed countries and the national development strategy of developing countries.

Exaggerated fear of or a real fiscal deficit resulted in policy measures to reduce the public provision of social services. Many developing countries began to unravel the various forms of social protection measures which had been established within the contexts of the developmentalism, socialist ideology and nation building(Mkandawire, 2005). The imposition of conditionality attached to loans to developing countries by the international financial institutions accelerated the unravelling process.

Different types of unravelling processes are discernable. Firstly, there was a group composed of those developing countries following broadly a liberal strategy based on the privatization of social insurance, a reduced public social safety net, a shift towards targeted means-tested assistance, and a free market bias in labour market regulations such as most countries in Sub-Saharan Africa and East-Central Europe and some Latin American countries. Welfare systems of the countries in Latin America andin particular Sub-Sahara Africa were still underdeveloped when they had a severe financial crisis in the late 1970's and 1980's. International financial institutions imposed stabilisation polices to these countries, which contributed to dismantling existing key welfare programmes, already poor both in terms of quantity and quality, through the cutbacks in public expenditure and privatisation of social service. This was also accompanied by dismantling the social safety nets invisible in terms of social expenditure but vital to the well-being of the poor such as price subsidies and control.

Dismantling public social services through privatisation did not contribute to either fiscal soundness or social development in most cases. Money from the government coffer was continuously directed to the private sector to generate incentives for investment from the private sector or to appease a small segment who could afford the costs of private services 
and appropriate public subsidies to private services. Unequal power relations played a role in increasing economic and social inequality. For example, the beneficiaries of patronage insurance schemes in Chile were powerful enough to get subsidies attached to their private schemes and consequently increased the fiscal burden and inequality by transferring the burden to the non-beneficiaries in the forms of taxes (Esping-Andersen, 2000).

The ex-communist countries' initial reaction to the transition was to cushion the shock with various social protection and social security measures. Generous unemployment insurance was introduced and industrial redundancies were countered with attrition and early retirement. However, dramatic fall in revenues, coupled with unexpected levels of unemployment and income loss resulted in the collapse of the existing social security system and a uniform shift towards targeted means-testing(Esping-Andersen, 2000). The quality of public social service significantly deteriorated through the lack of investment and the exodus of health personnel to the private sector. The poor had more difficulties in getting access to public services because of the introduction of user charges, also common in the developing countries in Africa (Konate and Kanate, 2005, Menash, 2005, Kida and Mackintosh, 2005).

Those countries following heterogeneous policies under the pressure of structural adjustment from international financial organisations such as Brazil, Argentina and Costa Rica form a distinct group. They selectively adopted the policy recommendations from international financial institutions and took some steps towards strengthening their public social safety nets and adopting a fairly universalistic approach in organising welfare system. Thus, Brazil has created the legal foundations for a universalistic welfare sate, in particular the health and education sector. Argentina adopted pension reform with part of the new system modelled after the Chilean case but maintained a universal basic pension. Costa Rica has advanced further than any other Latin American country in the extension of a welfare state inspired by the social democratic principles of universality and equity (Huber, 1996). Brazilwith targeted conditional cash transfers praised as the most successful case by international financial institutions shows the importance of research for welfare programmes within a broad economic, social and political context because Brazil's democratisation, active participation of civil society and universalisation of health and education services are the context where the targeted conditional cash transfer programme is situated. The fact that the targeted conditional cash transfer was originally considered as a first step towards universal citizens' income is 
also noticeable in the research of universalism (Bastagli, 2008). As a case under a different type of international pressure, Iranian policy which replaces fuel subsidies with universal cash transfer can also be categorised as a case of this group(Tabatabai, 2010).

There have also been cases with heterogeneous policy responses such as many countries in East Asia. Beginning with a strong informal welfare system of families, relatives and communities on the one hand, and a long tradition of education on the other, in such countries as South Korea and Taiwan, occupationally segmented social insurance schemes were developed and universal welfare in terms of coverage was achieved after democratisation. The role of government as financier in terms of its share of finance, although very low against the average of other OECD countries, varied depending on the insurance and service schemes for segments of society such as formal workers, farmers, self-employed and informal workers. Negotiated democratisation between the outgoing authoritarian elites and incoming democratic force, in particular in the cases of Taiwan and Korea, played a significant role in expanding the coverage of social insurance and services and consequently achieving universal coverage (Yi, 2010). Dynamic economic growth, active civil society and trade unions contributed to organising labour market, social transfer and social service system on the universal principle.

In the late 1990's, when concern about growing poverty and inequality increased, social policy was brought back as one of main policy approaches to reduce poverty, even in the agencies which had initiated the structural adjustment programme responsible for the accelerated unravelling process of social protection and social security programmes. The return, however, was in a very much residual form. The role of the private sector in the provision of social security and social service was emphasised as against the public sector on the one hand, and the targeting approach became the guiding principle of or at least a key important component of social policy, on the other. 


\section{Universalism and Targeting Approach: A Principle and A Method}

The history of social policy development in developing countries shows diverse approaches of social policy to reduce poverty and inequality. How different are they and what is the desirable approach of social policy in terms of the reduction of poverty and inequality? We will address these questions by examining universalism as an organising principle of social transformation on the one hand, and the targeting approach and commercialisation of social services, the major institution and predominant trend of the current development strategy to reduce poverty and inequality, on the other.

\section{Universalism as an Organising Principle of Social Transformation}

Most debate on universalism and the targeting approach in developing countries revolves around the eligibility criteria or allocation of benefits and services of each approach. In these debates, universalism denotes the idea of benefits and services being made available to an entire population as a social right while the targeting approach or selectivity infers the idea of benefits being made available on the basis of individual need determined by administrative discretionary measures such as a means test (Gilbert and Specht, 1974).

This usage of the term "universal" is in stark contrast with those architects of universal social insurance and services such as Titmuss and Beveridge in Britain, Möller and Wigforss in Sweden, and Zeuthen and Steincke in Denmark during the formative period of welfare states after the Second World War(Tilton, 1979, Esping-Andersen and Korpi, 1987, Reisman, 2001). To those, universalism was an organizing principle of social transformation which was manifested in the form of the welfare state. The eligibility criteria or coverage was just one of the indicators reflecting the social reform they envisioned. The major concern of universalism in their mind was how to re-organise production, redistribution, protection and reproduction within democratic polity. What they wanted to rid from society through this structure was not only poverty but various kinds of deprivation in economic, social and political spheres,described as evils in Beveridge's seminal report. Social protection measures, be they social insurance or social assistance, were only a part of this social transformation aiming at a society free from the political, social and economic evils of society. 
Social transformation based on universalism came from the recognition that society should not allow the social costs to be disproportionately borne by only some members of society. Following the recognition that the causes of individual misfortune resulting from social progress cannot be attributed to the individual alone, the idea developed that society as a whole should pay the price for some people bearing part of the cost of other people's progress(Titmuss, 1968). Those who could not earn an adequate income due to unemployment, retirement and illness, and had to rely on families and communities due to demographic change, it was now argued, would have their needs addressed by society collectively.

Universal social insurance and social services were the policy tools to make members of society benefiting from the society pay the costs of the progress. Expanded coverage, be they social security or services, alone could not be the sole factor to achieve universalism, since the most important parameter was whether the whole institutional configuration of society was designed and implemented in the way to actually pay the bill for those who bore the costs of the economic and social changes which benefited society as a whole. It was universal not only because everybody had entitlementbut also because everybody with an adequate income should pay for the costs, which was the real meaning of collective responsibility. Within this context, redistribution was an integral component of universalism, since the costs of social progress was not evenly distributed, i.e. it fell disproportionately on the poor and the vulnerable and there should be redistributive measures to pay for the poor and the vulnerable. For this collective responsibility and imperative of redistribution to be realized as policies through the political process, there should be political, social and economic incentives to all the members of society, in particular those actually paying the bill.

Strong policy pursuit for full employment played a significant role in reducing disincentives to pay for the costs of universal social protection, in particular social security for unemployment. Those arguing for universalism during the formative period of welfare states either assumed full employment and economic development generating jobs or emphasized the need for them. The policies, be they economic or social, were organized in such as way as to increase employment or to avoid adverse labor market incentives. It is well known that Beveridge, who was very much supported by Keynes, had a very optimistic view of full employment based on the experience of the war-time employment rate. In the same vein, Swedish social democrats did not hesitate to co-operate with capitalists to increase employment 
after the Second World War (Tilton, 1979, Townsend, 2004). Economic growth based on job creation which secured resources for the state to distribute welfare benefits and services was an integral component of universalism.

In the countries pursuing universalism in social protection and social security, there were mechanisms of social dialogue between the capital and the labour which generated economic incentives for universalism to both parties. Capitalists could get the benefits from the stability of the economy through the regulation of the labour market and products market by making concession to the extent which their reasonable profits were not greatly reduced while labour could get the job security and enhancement of living standards. Within the context of Keynesian demand-driven macroeconomic management, this mechanism provided policy makers with a framework of the main policy tools in the economic sphere, in particular in fiscal and labour market policy. A centralised coordination mechanism to regulate the labour market was developed and politics was shaped along the line of representation of interests of capital, workers and farmers (Tilton, 1979, Townsend, 2004).

The system of universal social security funded by tax or contribution was regulated by government's intervention into the functional distribution of income through various policy measures. Governments intervened into various areas such as industrial relations, industrial and trade policy to sustain the level of income of workers as a whole, the major revenue base of the universal social provisioning. Intervention into ownership and control of assets (including both physical capital and labour skills) and taxation of personal income and wealth were another policy corrective of functional income distribution. Together with the legislations on the social provision themselves, these interventions also affected the size of social security and service benefits through the control of the size of resources for social security and service. Protectionist measures in international trade were also closely related to welfare state arrangements since they critically affected the market incomes (and the size of benefits) of workers and farmers depending on the position of the country in the world trade system (Castles, 1996, Stephens, 1996).

The systems of social welfare provision such as tax-based finance and public provision should be designed and implemented along with a social planning for full employment and redistribution. Values such as social cohesion and equity and the resources to make welfare 
provision affordable and available to all were realized in policies across the sectors, not only in social protection and social security. The goal of these policies was to reinstate those who had been victimized during the process of development back to the positions where they could exert their potentials through the minimum but adequate social services on the one hand, and gainful employment on the other. As such, universal social provision of benefits and services was not the result of the intervention into social protection and social security alone but also the interventions into economic sphere such as production and distribution of functional incomes.

Being a comprehensive framework of social transformation, often labeled the welfare state, universal social transfers and services were clearly recognized as investment as well as consumption. Improved levels of living are a pre-condition for higher labour input and efficiency which were favourable to rising productivity, which some countries already experienced through various battles and wars. In this light, universal social provision of benefits and services were considered to be the best institutional arrangements for increased productivity and efficiency as well as the reduction of poverty and equality.

\section{Universalism vs. Targeting in the Social Protection, Social Security and Social Service}

As we have seen in the previous section, since the late 1970s, in both developed and developing countries, the principle of social provision of social transfers and services shifted from universalism to targeting in the midst of a shift in ideology towards neo-liberalism with its emphasis on individual responsibility for individual misfortune and the limited role of the state on the one hand,and a spreading fiscal crisis on the other. One of the significant changes within academic discourse with regard to this policy shift was that the discourse on social protection and social security was narrowed down from a long-term transformative planning questioning how to organise a whole society to a highly technical question of how to distribute benefits and costs.

Targeting as a principle of distribution of benefits and costs has two tasks; identifying those responsible for their own misfortunes and reducing "social wages" or "social costs" by 
excluding the non-poor. The argument that universal social protection and social securityis costly and ineffective in reducing poverty often leads to the emphasis on the social safety net which the so called "pro-poor" policies also enthusiastically pursued. "Well targeted transfers" and "safety nets" became major instruments for poverty reduction within the frameworks of "pro-poor growth" and "new managerialism".

In theory, targeting schemes, through various ways to identify the poor ranging from simple self-targeting models to more complicated poverty mapping models through means testing, can allocate limited resources earmarked for social transfers to a designated subgroup of the population, generally excluding those not in need. Therefore, it can concentrate resources on the poor. Based on this theory those proponents for targeting schemesargue that it can improve efficiency in delivering benefits and services to the poor and therefore reduce the high leakage of resources found within universal schemes. They also argue that targeting is much more progressive, i.e. more redistributive in favour of the poor, than universalism because the benefits are concentrated in the poor.

A lot of theoretical and empirical evidence challenges thearguments for the targeting approach. Firstly, there is the cost effectiveness argument. Although comprehensive data on the costs involved in the identification of the poor and the monitoring of various types of irregularity in delivering and receiving benefits, many researchers agree that targeted programmes are far more costly than universal programmes since identifying the poor in developing countries demands a lot of resources (Smith and Subbarao, 2003). The process of identifying the poor requires extra resources such as the costs for continuously updating tools for the identification of the poor and for fraud control. Using more advanced tools to identify the poor such as computerized database and magnetic card system in Brazil would minimize errors but would also further increase costs (Dutrey, 2007).

[Table 1] shows that the efficiency of targeted schemes is the same as that of universal schemes when taking into account a standard ratio of leakage and under-coverage of a successful targeted scheme as in the cases of Example 3 and 4 and when including all the poor. Adding the administrative cost of the target group identification and transferring will further reduce the efficiency of the targeted schemes compared to universal schemes. 
$\langle$ Table 1〉 Simulations of efficiency

\begin{tabular}{|c|c|c|c|c|c|c|c|c|c|}
\hline $\begin{array}{l}\text { Form } \\
\text { of } \\
\text { provision }\end{array}$ & $\begin{array}{c}1 \text { st } \\
\text { quintile }\end{array}$ & \begin{tabular}{c|} 
2nd \\
quintile
\end{tabular} & $\begin{array}{c}\text { 3rd } \\
\text { quintile }\end{array}$ & $\begin{array}{c}4 \text { th } \\
\text { quintile }\end{array}$ & $\begin{array}{l}\text { 5th } \\
\text { quintile }\end{array}$ & $\begin{array}{l}\text { "targeting } \\
\text { efficiency" }\end{array}$ & $\begin{array}{l}\text { Benefit } \\
\text { per poor } \\
\text { individual }\end{array}$ & $\begin{array}{c}\text { Under- } \\
\text { coverage } \\
(\%)\end{array}$ & $\begin{array}{c}\text { Leakage } \\
(\%)\end{array}$ \\
\hline $\begin{array}{c}1 . \\
\text { Universal }\end{array}$ & $200 / 4$ & $200 / 4$ & $200 / 4$ & $200 / 4$ & $200 / 4$ & 1.0 & 50 & 0 & 0 \\
\hline $\begin{array}{c}2 . \\
\text { Ideally Targeted }\end{array}$ & $500 / 4$ & $500 / 4$ & $0 / 4$ & $0 / 4$ & $0 / 4$ & 2.5 & 125 & 0 & 0 \\
\hline $\begin{array}{c}3 . \\
\text { "Standard" leakage: } \\
\text { all poor coverage }\end{array}$ & $340 / 4$ & $340 / 4$ & $200 / 4$ & $100 / 4$ & $20 / 4$ & 1.7 & 85 & 0 & If 32 \\
\hline "Standard" coverage & $\begin{array}{l}500 / 2 \\
(0 / 2)\end{array}$ & $\begin{array}{l}500 / 2 \\
(0 / 2)\end{array}$ & 0 & 0 & 0 & 5 & $250(0)$ & If 50 & 0 \\
\hline $\begin{array}{l}\text { "Standard" leakage: } \\
\text { "Standard" coverage }\end{array}$ & $\begin{array}{l}340 / 2 \\
(0 / 2)\end{array}$ & $\begin{array}{l}340 / 2 \\
(0 / 2)\end{array}$ & 200 & 100 & 20 & 3.4 & $170(0)$ & If 50 & If 32 \\
\hline $\begin{array}{c}4 . \\
\text { Bolsa Familia(2004) }\end{array}$ & \begin{tabular}{|l|}
$255 / 1,96$ \\
$(0 / 2,04)$
\end{tabular} & \begin{tabular}{|l|}
$255 / 1,96$ \\
$(0 / 2,04)$
\end{tabular} & 303 & 155 & 32 & 5.2 & $130(0)$ & 59 & 49 \\
\hline
\end{tabular}

This calculation is based on the assumption that a fixed budget of 1000 units are allocated for social programmes and given that there are four people in each quintile group. Source: (Dutrey, 2007, Soares et al., 2007).

Secondly, the accuracy of targeting has been consistently controversial. It has been criticized that due to information gaps and insufficient data for defining the poor, accurate targeting cannot be achieved. Misreporting also leads to exclusion errors (under-coverage) and inclusion errors (leakage). Even those targeting schemes praised by UNESCO, the IMF and World Bank as "success stories" in terms of their targeting accuracy such as Bolsa Escola and Bolsa Familia of Brazil (which are cash transfers conditional on school attendance and vaccination), the Subsidized Health Insurance Regime (SHIR, health social assistance) of Colombia, and the conditional cash transfer of Progresa (later called Oporunidades, a poverty alleviation programme) of Mexico, all suffer from a substantial under-coverage rate which excludes those people in need who should be covered (Dutrey, 2007, Soares et al., 2007).

Thirdly, redistributive effect of targeting schemes. Much-cited report on targeting by Coady et al (Coady et al., 2004), a major reference for those supporting targeting schemes, showed that the median targeting programme transferred 25 per cent more to poor individuals than a universal programme based on their evaluation of 122 antipoverty targeting interventions in 48 countries in various parts of the world. However, there are serious weaknesses in 
these findings. According to the report itself, up to 25 per cent of all targeting schemes have proven to be regressive, transferring fewer resources to the poor than under universal schemes. In these cases, what was initially designed to target the poor, in practice, has ended up targeting resources to the non-poor, i.e. "inclusion error". In addition, the countries with low gross domestic product had less number of successful targeting schemes. The vast majority of the best performers in the study are located in the least poor countries. The so called successful schemes with 25 per cent more benefits to the poor did have problems too. Since they reported targeting efficiency included only those poor receiving benefits, and not all of the poor, there is a high possibility that a vast majority of the poor was excluded from these schemes (Dutrey, 2007). It is partly supported by the report on one of the most successful targeting schemes, Bolsa Familia which reports 44 per cent of the eligible families were not covered by the scheme in 2006 (Soares, 2010).

Despite the significant number of the eligible poor excluded from the scheme, most targeted schemes place a strict focus and priority on preventing leakages, i.e. benefits to the noneligible. Being placed just above or below the poverty line under these circumstances means that access to benefits is not guaranteed. This may undermine the feeling of being involved within a society and promote the deceitful behaviour of individuals against society such as benefit fraud. Problems related to cheating, arbitrariness and discrimination are more associated with targeted schemes than universal schemes (Kumlin and Rothstein, 2005). Targeted schemes intensify the feelings of those above the poverty line to be either excluded from the society when they could not benefit from the scheme or guilty to other fellow members when they cheated. For those below the poverty line, the fears to be excluded when they receive benefits or feelings treated unfairly when they could not receive benefits increase. As a result, the experience of stigmatization and social division is common to all. The resulting discriminatory effects of the targeted approach is therefore the worst one we get in the development context because it creates divisions even among the poor. It withholds resources from some of the poor and concentrates them on what becomes a "privileged poor", who are often the most easily accessible either administratively or culturally (Dutrey, 2007).

Finally, but not the least, there is the issue of the sustainability of the targeting scheme. A targeting scheme is less likely to be politically sustainable since the support of middle class for targeted scheme is easily lost during recession on the one hand, and the poor who are 
politically weak in most cases cannot form a strong political force to maintain targeting scheme, in particular during political and economic crisis.

\section{Commercialisation of the Provision of Social Transfers and Services}

The dominance of neo-liberal policy trend emphasising privatisation and small government during the 1980s and 1990s had a significant impact on social protection and social security, in particular the social service sector. These reforms were advocated to improve efficiency by bringing in choice and competition through various forms of public and private mix in finance and delivery. The governments of developing countries commercialized basic social services through a variety of cost recovery measure such as vouchers and user charges. Contracting out the management of basic social services from public to private providers was also one of the commercialization measures. Such factors as lack of government resources, low-quality public provision and pressure to liberalise economy resulted in the private sector's growing role in social service provisions (Mehrotra and Delamonica, 2007). The reforms were pursued in most advanced countries and almost all developing countries heavily dependent upon international donors (Independent Evaluation Office, 2003). The statistics show that this neo-liberal reform negatively affected the general health and education standards in these countries. The social indicators which had been significantly improved between 1960 and 1980 in many developing countries, particularly in Sub-Sahara Africa region, were reversed during the 1980s (Adesina, 2007).

- Underfunded public sector and commercialization of the social services were the main causes of the declining health and education outcomes. The lack of government investment in the social service reduced the size and deteriorated the service of the public sectors. The area with poorer infrastructure where poverty is usually concentrated suffered most from the decreasing public services. Health professionals and teaching staff moved from the public sector to the private sector for better salaries and working conditions, either within or outside the country. The reduced availability of service and low quality of public sector service provision such as staff with poor qualification, overcrowded classrooms and long queues for the treatment or the perception of such inadequancy led people to go without services or opt out for private service providers which put more financial burden on the users than the public service (Konate and Kanate, 2005). Much worse was that 
the increasing private sector at the expense of the public sector did not always result in high efficiency and quality of service in private sector in return(Mills, 1997, Menash, 2005, Bennett, 1997, Bennett and Tangcharoensathien, 1994).

- The commercialization of service such as the introduction of school fees and out-ofpocket payment has worsened equity in service provisions. Poor families sending their children to schools suffered from the direct and indirect costs and children from poor families recorded high drop-out rates even at the primary level education. The most serious effect in health sector was that services were refused on account of inability to pay, and illness went untreated because of the financial burden because of high out of pocket payment.

- The impact of neoliberalism on social servicesat the global level is also noticeable. As a result of globalization and the domination of free trade ideology, the newly established international trade regime headed by the WTO began to profoundly influence health and education policies. In developing countries, health policy related to physical and human resources is increasingly affected by trade agreements such as the Trade-Related Aspects of Intellectual Property Rights (TRIPS) agreement and the General Agreement on Trade in Service (GATS) (Sun, 2005, Chaudhuri, 2005). Although the long-term effect of TRIPS and GATS is debatable, it is difficult to deny that the current framework of TRIPS and GATS is reinforcing inequality between countries.

\section{A New Social Policy Approach : Transformative Social Policy}

Social policy had not had a place in the development discourse until recently since it has been considered an unattainable luxury for developing countries or incompatible with lowincome contexts. Poor results of neo-liberal strategy in terms of the reduction of poverty and inequality facilitated the return ofsocial policy as a main component of development strategy since the 1990s but as a residual form such as safety net. The retrenchment of the public sector, the expanding private sector, the less regulation of the state and the targeting approach were the main features of the returning social policy and had a negative impact on the reduction of poverty and inequality. 
Then what is the desirable social policy approach to reduce poverty and inequality? "Transformative Social Policy (hereafter TSP)" which has been employed by many researchers including UNRISD is an approach addressing various problems of the current social policy approach. One of the fundamental assumptions differentiating TSP from other approaches is regards the relationship between the social and the economic. Neo-liberal thinking assumes that the economic is autonomous from the social and only the market mechanism can provide the ultimate solutions to various economic and social problems. Despite varying degrees of confidence in the role of market, this line of thinking mainly considers social policy only complementary to the economic policy.

In contrast to this, TSP approach is based on the assumption that the economic is deeply embedded in the social, and the capitalist economy doesnot mean exclusively market economy but an entity composed of diverse forms of economies such as gift-giving and moral economies which are based on solidarity, obligation, respect and harmony as well as market economy. This perspective shares in common with Polanyian view that within capitalist society, the market economy is one of many economies existing within society (Polanyi, 1944, Scott, 1976). Within the TSP approach, the market economy is not an autonomous and self-regulating mechanism. Many studies, in particular studies in the discipline of economic anthropology show economic behaviour and economic relations are affected by various interpersonal and social relations in a variety of ways. Social relations such as tribes, castes and kinship in developing countries in particular have acted as filters for the spread of market mechanisms, causing important variations in patterns of development of market economy (Brohman, 1995).

Within the TSP approach, despite its concern with poverty and inequality, the ultimate function or impact of social policy is not confined to supporting those casualties whose needs have not been met by the market economy. Its purpose is to address the collective risks of society composed of many economies affected by economic, social and political relations. Social policy within this context, therefore, needs to be concerned with the production of power and resources, protection of the vulnerable in terms of power and resources, redistribution of wealth and power, and reproduction of human and environment. Within the TSP approach social policy is a measure to organise the social, economic and political relations contributing to social transformation based on universalism. It is in line with the 
recognition of one of the welfare states architects, Richard Titmuss, that what universal social insurance and social services provided was not only the benefits per se which can be provided out of either charity or obligation but the transformation reinstating the victims of economic and social change of society as a full member of the society(Titmuss, 1968). TSP with its analytical focus on the institutional relations between and within the political, economic and social spheres at various levels and its goals to change the relationships of people and institutions for social cohesion and solidarity can offer a great advantage to research on a system of economic growth, thick democracy, and poverty reduction. Politics has a great importance in this approach since the intensity and comprehensiveness of the linkages between policy boundaries and of institutions across these dimensions are dependent upon a complex interplay of forces unique to each country(Mkandawire, 2004).

\section{Conclusion}

From this review of the evolution of social policy in the name of social protection, social security, and social service, we can learn that social policy was not only a protective measure but a set of public policies which intervened in production, redistribution, protection and reproduction and played a critical role in facilitating economic growth as well as combating poverty and inequality. It was understood, designed and implemented within a broad policy framework for social transformation which can consequently reduce poverty and inequality rather than a policy framework specifically aiming at the poverty per se (social protection).

One of the policy lessons with regard to social protection and social security would be that achieving universal coverage, which is widely agreed to be the essential component of the anti-poverty strategy, can only be realised through the intervention of the state into production, redistribution and reproduction as well as protection. It reconfirms the importance of comprehensive and holistic approach to social policy to reduce poverty and inequality.

The transformative social policy approach based on the universalism principle which intervenes into all the major functions of society such as production, redistribution, protection and reproduction would be the one approach capable to address the problems of current dominant approach of social policy, privatization and targeting in developing countries. 


\section{Bibliography}

ADESINA, J. 2007. In Search of Inclusive Development: Introduction. In: ADESINA, J. (ed.) Social Policy in Sub-Saharan African Context. Basingstoke and New York: Palgrave Macmillan.

ADESINA, J. 2010. Transformative Social Policy and the Return to Wider Vision: Re-reading Theory and History. The International Sociological Association World Congress. Gotheborg.

ARRIGHI, G. 2002. The African Crisis. New Left Review, 15, 5-36.

ARRIGHI, G. \& SAUL, J. 1973. Essays on the Political Economy of Africa, New York, Monthly Review Press.

BARRIENTOS, A. 2004. Latin America: Towards a Liberal-Informal Welfare Regime. In: GOUGH, I. \& WOOD, G. (eds.) Insecurity and Welfare Regimes in Asia, Africa and Latin America. Cambridge: Cambridge University Press.

BASTAGLI, F. 2008. The Design, Implementation and Impacts of Conditional Cash Transfers Targeted on the Poor: An Evaluation of Brazil's Bolsa Familia. PhD, London School of Economics and Political Science.

BENNETT, S. 1997. Private Health Care and Public Policy Objectives. In : COLCLOUGH, C. (ed.) Marketizing Education and Health in Developing Countries: Miracle or Mirage. Oxford: Clarendon Press.

BENNETT, S. \& TANGCHAROENSATHIEN, V. 1994. A Striking State-Politics, Economics and Private Health Care in Thailand. Public Administration and Development, 14, 1-17.

BONILlA GARCIA, A. \& GRUAT, J. V. 2003. Social Protection A Life Cycle Continuum Investment for Social Justice, Poverty Reduction and Sustainable Development. Geneva: ILO.

BOWLES, S., GORDON, D. M. \& WEISSKOPF, T. E. 1990. After the Waste Land : A Democratic Economics for the Year 2000, New York, M.E. Sharpe, Inc. 
BROHMAN, J. 1995. Universalism, Eurocentrism, and Ideological Bias in Development Studies : From Modernisation to Neoliberalism. Third World Quarterly, 16, 121-140.

CASTLES, F. 1996. Needs-Based Strategies of Social Protection in Australia and New Zealand. In: ESPING-ANDERSEN, G. (ed.) Welfare States in Transition. London: Sage and UNRISD.

CHAUDHURI, S. 2005. Indian Phamaceutical Companies and Accessibility of Drugs under TRIPS. In : MACKINTOSH, M. \& KOIVUSALO, M. (eds.)

Commercialization of Health. Basingstoke and New York: Palgrave Macmillan.

COADY, D., GROSH, M. E. \& HODDINOT, J. 2004. Targeting of Transfers in Developing Countries: Review of Lessons and Experience. Washington, D.C. : World Bank.

DAVID, C. \& HUANG, J. 1996. Political Economy of Rice Price Protection in Asia. Economic Development and Cultural Change, 44, 463-483.

DUTREY, A. P. 2007. Successful Targeting? Reporting Efficiency and Costs in Targeted Poverty Alleviation Programmes. Geneva: United Nations Research Institute for Social Development.

ESPING-ANDERSEN, G. 2000. After the Golden Age? Welfare State Dilemma in a Global Economy. In: ESPING-ANDERSEN, G. (ed.) Welfare States in Transition: National Adaptations in Global Economies. London: Sage and UNRISD.

ESPING-ANDERSEN, G. \& KORPI, W. 1987. From Poor Relief to Institutional Welfare States: The Development of Scandinavian Social Policy. In: ERIKSON, R. E. (ed.) The Scandinavian Model: Welfare States and Welfare Research. New York: M.E. Sharpe, Inc.

FERREIRA, F. \& ROBALINO, D. 2010. Social Protection in Latin America. Washington, D.C.: The World Bank.

FILGUEIRA, C. H. \& FILGUEIRA, F. 2002. Models of Welfare and Models of Capitalism: The Limits of Transferability. In : HUBER, E. (ed.) Models of Capitalism:

Lessons for Latin America. Pennsylvania: The Pennsylvania State University Press. 
FISZBEIN, A. 2005. Beyond Truncated Welfare States: Quo Vadis Latin America? Washington, D.C.: The World Bank.

GENERAL ASSEMBLY OF UNITED NATIONS. 1966. International Covenant on Economic, Social and Cultural Rights [Online]. Geneva: Office of the United Nations High Commissioner for Human Rights. [Accessed December 10 2010].

GILBERT, N. \& SPECHT, H. 1974. Dimensions of Social Welfare Policy, Englewood Cliffs, Prentice-Hall, Inc.

HUBER, E. 1996. Options for Social Policy in Latin America: Neoliberal versus Social Democratic Models. In: ESPING-ANDERSEN, G. (ed.) Welfare States in Transition : National Adaptations in Global Economies. London: Sage and UNRISD.

INDEPENDENT EVALUATION OFFICE 2003. Evaluation of the Prolonged Use of IMF Resources. Washington, D.C. : Independent Evaluation Office, IMF.

INTERNATIONAL LABOUR ORGANIZATION. 1952. The ILO Social Security (Minimum Standards) Convention, 1952 (No.102) [Online]. Geneva: International Labour Organization,. Available : http://www.ilo.org/public/english/protection/secsoc/ areas/legal/legal.htm [Accessed December 92010 2010].

INTERNATIONAL LABOUR ORGANIZATION 2010. World of Work Report 2008. Geneva : International Labour Organization.

KIDA, T. \& MACKINTOSH, M. 2005. Pubilc Expenditure Allocation and Incidence under Health Care Market Liberalization : a Tanzanian Case Study. In : MACKINTOSH, M. \& KOIVUSALO, M. (eds.) Commercialization of Health. New York: Palgrave Macmillan.

KONATE, M. \& KANATE, B. 2005. Commercialization of Health Care in Mali : Community Health Centres, Fees for Social Service and the Rise of Private Providers. In : MACKINTOSH, M. \& KOIVUSALO, M. (eds.) Commercialization of Health Care. New York: Palgrave Macmillan.

KUMLIN, S. \& ROTHSTEIN, B. 2005. Making and Breaking Social Capital: The Impact of Welfare State Institutions. Comparative Political Studies, 38, 339-365. 
KWON, H.-J. \& YI, I. 2009. Economic Development and Poverty Reduction in Korea : Governing Multiple Institutions. Development and Change, 40, 769-792.

MEHROTRA, S. \& DELAMONICA, E. 2007. Eliminating Human Poverty, London and New York, zed Books.

MENASH, K. 2005. International Migration of Health Care Staff : Extent and Policy Responses, with Illustration from Ghana. In: MACKINTOSH, M. \& KOIVUSALO, M. (eds.) Commercialization of Health. New York: Palgrave Macmillan.

MILLS, A. 1997. Improving the Efficiency of Public Sector Health Service in Developing Countries: Bureacratic versus Market Approaches. In: COLCLOUGH, C. (ed.) Marketizing Education and Health in Developing Countries: Miracle or Mirage. Oxford: Clarendon Press.

MKANDAWIRE, T. 2001. Social Policy in a Development Context. Geneva : United Nations Research Institute for Social Development.

MKANDAWIRE, T. 2004. Social Policy in a Development Context: Introduction. In : MKANDAWIRE, T. (ed.) Social Policy in a Development Context. New York: Palgrave Macmillan.

MKANDAWIRE, T. 2005. Targeting and Universalism in Poverty Reduction. Social Policy and Development Programme Paper. Geneva : UNRISD.

MOLYNEUX, M. 2007. Change and Continuity in Social Protetion in Latin America. Geneva : UNRISD.

MYRDAL, G. 1968. Asian Drama, New York, Pantheon.

ORTIZ, I., CHAI, J., CUMMINGS, M. \& VERGARA, G. 2010. Prioritizing Expenditure for a Recoverty for All. UNICEF Social and Economic Policy Working Paper. UNICEF Social and Economic Policy Working Paper ed. New York: UNICEF.

POLANYI, K. 1944. The Great Transformation, New York, Holt, Rinehart.

REISMAN, D. 2001. Richard Titmuss Welfare and Society, Basingsoke and New York, Palgrave. 
RINGEN, S., KWON, H.-J., YI, I., KIM, T. \& LEE, J. 2011. The Korean State and Social Policy, Oxford, Oxford University Press.

SCOTT, J. 1976. The Moral Economy of the Peasant, Haven, Yale University Press.

SMITH, W. \& SUBBARAO, K. 2003. What Role for Safety Nets in Very Low Income Countries? Washington, D.C.: The World Bank.

SOARES, F., RIBAS, R. \& OSORIO, R. 2007. Evaluating the Impacts of Brazil's Bolsa Famila: Cash Transfer Programmes in Comparative Perspective. Brasilia: International Poverty Centre.

SOARES, S. 2010. Targeting and Coverage of the Bolsa Familia Programme: What is the Meaning of Eleven Million Families. Brasilia: International Policy Centre for Inclusive Growth.

STEPHENS, J. D. 1996. The Scandinavian Welfare Staes: Achievements, Crisis, and Prospects In : ESPING-ANDERSEN, G. (ed.) Welfare States in Transition. London : Sage and UNRISD.

SUN, Q. 2005. The Interactions between Social and Commecial HealthInsurance after China's Entry into the World Trade Organiszation. In: MACKINTOSH, M. \& KOIVUSALO, M. (eds.) Commercialization of Health Care. Basingstoke and New York: Palgrave Macmillan.

TABATABAI, H. 2010. The "Basic Income" Road to Reforming Iran's Subsidy System. the 13th International Congress of the Basic Income Earth Network. Universidade de Sao Paulo, Sao Paulo, Brazil.

TILTON, T. 1979. A Swedish Road to Socialism: Ernest Wiigforss and the Ideological Foundations of Swedish Social Democracy. The American Political Science Review, $73,505-520$.

TITMUSS, R. 1968. Commitment to Welfare, London, Allen and Unwin Ltd.

TOWNSEND, P. 2004. From Universalism to Safety Nets: The Rise and Fall of Keynsian Influence on Social Development. In: MKANDAWIRE, T. (ed.)Social Policy in a Development Context. Basingstoke and New York: Palgrave Macmillan. 
TOWNSEND, P. 2007. The Right to Social Security and Natioanl Development: Lessons from OECD Experience for Low-income Countries. In : INTERNATIONAL LABOUR ORGANIZATION (ed.). Geneva: International Labour Organization.

TULCHIN, J. \& GARLAND, A. 2000. Social Development in Latin America: the Politics of Reform, Boulder, CO., Lynne Reinner Publishers.

YI, I. 2010. Development of Health System in Taiwan and South Korea. International Sociological World Congress. Gotheborg. 